\title{
Relation between Carcinoembryonic Antigen Levels in Colon Cancer Tissue and Serum Carcinoembryonic Antigen Levels at Initial Surgery and Recurrence
}

\author{
Gota Saito Sotaro Sadahiro Kazutake Okada Akira Tanaka Toshiyuki Suzuki \\ Akemi Kamijo \\ Department of Surgery, Tokai University School of Medicine, Kanagawa, Japan
}

\section{Key Words}

Colon cancer $\cdot$ Carcinoembryonic antigen $\cdot$ Metastasis

\begin{abstract}
Objectives: Carcinoembryonic antigen (CEA) is widely used for postoperative surveillance of colon cancer. Even if serum CEA is negative at initial surgery, it may turn positive at recurrence. We investigated the relation between serum CEA levels and the immunohistochemical staining status of CEA in the primary and resected metastatic tissues. Methods: Out of 224 patients with recurrent colon cancer between 1998 and 2012, we studied 46 patients in whom serum CEA levels were measured and immunohistochemical staining for CEA was possible in the primary and metastatic tissues. Results: The positive rate of serum CEA did not differ between initial surgery and recurrence, regardless of whether the cutoff value was set at 5 or $10 \mathrm{ng} / \mathrm{ml}(\mathrm{p}=0.829, \mathrm{p}=0.671)$. There was no relation between the CEA staining status and serum CEA level at initial surgery. However, the CEA staining status of metastatic tissue was significantly related to the serum CEA level at recurrence $(p=0.0046$ and $p=0.0026)$. Conclusions: The immunohistochemical staining status of CEA in metastatic tissue is closely related to the serum CEA level. This finding suggests that serum CEA levels are influenced not
\end{abstract}

\begin{tabular}{|c|c|}
\hline KARGER & $\begin{array}{l}\text { (c) } 2016 \text { The Author(s) } \\
\text { Published by S. Karger AG, Basel } \\
0030-2414 / 16 / 0912-0085 \$ 39.50 / 0\end{array}$ \\
\hline www.karger.com/ocl & $\begin{array}{l}\text { This article is licensed under the Creative Commons Attribution- } \\
\text { NonCommercial-NoDerivatives } 4.0 \text { International License (CC BY- } \\
\text { NC-ND) (http://www.karger.com/Services/OpenAccessLicense). } \\
\text { Usage and distribution for commercial purposes as well as any dis- } \\
\text { tribution of modified material requires written permission. }\end{array}$ \\
\hline
\end{tabular}

only by the CEA production capacity of cancer cells but also by the ability of the surrounding tissue to release CEA into the blood.

(c) 2016 The Author(s)

Published by S. Karger AG, Basel

\section{Introduction}

Carcinoembryonic antigen (CEA) is a set of glycoproteins extracted from colorectal cancer tissue by Gold and Freedman [1]. Because CEA was also found in extracts of human embryonic intestine, it was named 'carcinoembryonic antigen'. At present, CEA is widely used in clinical practice as a tumor-associated antigen for gastrointestinal cancer, particularly colorectal cancer [2]. The positive rate of serum CEA increases in parallel to the disease stage. Particularly high serum CEA levels are often found in patients with metastasis [3-8].

Because the serum CEA level frequently increases several months before recurrence is detected on conventional imaging studies, serum CEA measurement has been widely used for postoperative surveillance [9-13]. However, in some patients, serum CEA levels become positive despite the absence of recurrence, while in others the serum CEA level is positive at initial surgery but becomes

Prof. Sotaro Sadahiro

Department of Surgery, Tokai University School of Medicine

143 Shimokasuya Isehara

Kanagawa 259-1193 (Japan)

E-Mail sadahiro@ is.icc.tokai.ac.jp 
negative at the time of recurrence. The sensitivity and specificity of serum CEA for the detection of recurrence are thus not high $[14,15]$.

Some studies have reported a positive relation between CEA levels in cancer tissue and serum CEA levels [16], whereas others have found no relation between these variables [17-20]. Currently available findings remain controversial. Because the surrounding tissue environment differs between primary tumor tissue and metastatic tissue, the amount of CEA released from cancer cells into the blood might differ between primary tumors and metastatic lesions. We immunohistochemically evaluated the staining status of CEA in primary tumor tissue and metastatic tissue and studied the relations of the tissue CEA staining status to serum CEA levels.

\section{Methods}

From January 1998 through December 2012, we performed surgery in 1,306 patients with curatively resected pathological stage I, II, or III colon cancer in the Department of Surgery, Tokai University. The median postoperative follow-up in the surviving patients was 61.8 months. During follow-up, 224 patients (17.2\%) had recurrence. Serum CEA levels were measured at initial surgery and at the time of surgery for recurrence in 193 patients (14.8\%). We studied 46 of these patients in whom immunohistochemical staining for CEA was possible both in primary tumor tissue and metastatic tissue.

Serum CEA was assayed with the E-test 'TOSOH' II CEA system (TOSOH Inc., Tokyo, Japan), using a high-affinity anti-CEA monoclonal antibody. The cutoff value of CEA was set at $5 \mathrm{ng} / \mathrm{ml}$. The surgically resected tumor tissues were immediately fixed in $10 \%$ formalin and embedded in paraffin. Paraffin-embedded tumor specimens were cut into $3-\mu \mathrm{m}$-thick sections and subjected to immunohistochemical analysis. The primary antibody was mouse anti-CEA antibody (1:100; Leica, Newcastle, UK). After incubation with the primary antibody, the sections were incubated with the secondary antibody using the EnVision method (Dako, Glostrup, Denmark). The slides were counterstained with hematoxylin.

CEA staining in tumor tissue was evaluated as follows. Staining of the luminal cell membrane or the cytoplasm was evaluated according to a 3-grade scale of negative, positive, or strongly positive. Specimens in which the luminal cell membrane or the cytoplasm was strongly stained were defined as staining positive.

Statistical analyses were performed with the $\chi^{2}$ test and Fisher's exact test. Survival rates were calculated by the Kaplan-Meier method and were compared with the use of log-rank tests. $p$ values $<0.05$ were considered to indicate statistical significance. JMP ${ }^{\circledR} 11$ software (SAS Institute Inc., Cary, N.C., USA) was used for statistical analysis.

\section{Statement of Ethics}

This study was approved by the Institutional Review Board of Tokai University (13R-206).
Table 1. Clinicopathological characteristics of the patients at initial surgery

\begin{tabular}{|c|c|c|c|}
\hline & \multicolumn{2}{|c|}{$\begin{array}{l}\text { Serum CEA level at initial } \\
\text { surgery }\end{array}$} & \multirow[t]{2}{*}{$\mathrm{p}$} \\
\hline & $\begin{array}{l}<5 \mathrm{ng} / \mathrm{ml} \\
(\mathrm{n}=18)\end{array}$ & $\begin{array}{l}\geq 5 \mathrm{ng} / \mathrm{ml} \\
(\mathrm{n}=28)\end{array}$ & \\
\hline Mean age $\pm S D$, years & $61.7 \pm 9.9$ & $65.8 \pm 10.7$ & 0.203 \\
\hline Sex & & & 0.554 \\
\hline Male & 12 & 16 & \\
\hline Female & 6 & 12 & \\
\hline Histologic grade & & & 1.000 \\
\hline G1 & 9 & 13 & \\
\hline G2 & 9 & 15 & \\
\hline G3 & 0 & 0 & \\
\hline Lymphatic invasion & 15 & 25 & 0.666 \\
\hline Vascular invasion & 15 & 17 & 0.188 \\
\hline Location & & & 0.533 \\
\hline Right colon & 8 & 9 & \\
\hline Left colon & 10 & 19 & \\
\hline T stage & & & 1.000 \\
\hline $\mathrm{T} 1, \mathrm{~T} 2$ & 1 & 2 & \\
\hline T3, T4 & 17 & 26 & \\
\hline $\mathrm{N}$ stage & & & 0.232 \\
\hline No & 12 & 13 & \\
\hline $\mathrm{N} 1, \mathrm{~N} 2$ & 6 & 15 & \\
\hline First site of recurrence & & & 0.756 \\
\hline Liver & 6 & 8 & \\
\hline Lung & 3 & 4 & \\
\hline Peritoneum & 2 & 7 & \\
\hline Others & 7 & 9 & \\
\hline
\end{tabular}

\section{Results}

Table 1 shows the clinicopathological characteristics of the 46 patients according to whether the serum CEA level was negative or positive at initial surgery. There were no differences in age, sex, histologic grade, lymphatic invasion, vascular invasion, tumor location, $\mathrm{T}$ stage, $\mathrm{N}$ stage, or first site of recurrence between the two groups.

The rates of positive serum CEA levels at initial surgery and recurrence are shown in table 2 . The rates of positive serum CEA levels did not differ between the time of initial surgery and the time of recurrence, regardless of whether the serum CEA cutoff value was set at 5 or $10 \mathrm{ng} /$ $\mathrm{ml}$ (table 2).

The rates of positive staining for CEA in the primary tumor tissue and metastatic tissue are shown in table 3. The rate of positive staining for CEA was slightly but not significantly higher in metastatic tissue than in primary tumor tissue (table 3). 
Table 2. Serum CEA levels at initial surgery and recurrence

\begin{tabular}{llllllll}
\hline & \multicolumn{2}{l}{ Serum CEA level } & $\mathrm{p}$ & & \multicolumn{2}{l}{ Serum CEA level } & $\mathrm{p}$ \\
\cline { 2 - 3 } & $<5 \mathrm{ng} / \mathrm{ml}$ & $\geq 5 \mathrm{ng} / \mathrm{ml}$ & & & $<10 \mathrm{ng} / \mathrm{ml}$ & $\geq 10 \mathrm{ng} / \mathrm{ml}$ & \\
\hline Initial surgery & $18(39.1)$ & $28(60.9)$ & 0.829 & $29(63.0)$ & $17(37.0)$ & 0.671 \\
Recurrence & $16(34.8)$ & $30(65.2)$ & & $26(56.5)$ & $20(43.5)$ & \\
\hline
\end{tabular}

Values are expressed as $\mathrm{n}(\%)$.

The relation between serum CEA levels at initial surgery and the CEA staining status of primary tumor tissue is shown in table 4 . There was no association between the CEA staining status of the primary tumor and the serum CEA level at initial surgery, regardless of whether the serum CEA cutoff value was set at 5 or $10 \mathrm{ng} / \mathrm{ml}$ (table 4 ).

The relation between serum CEA levels at recurrence and the CEA staining status of metastatic tissue is shown in table 5. When the cutoff value of serum CEA was set at $5 \mathrm{ng} / \mathrm{ml}, 16$ patients had negative serum CEA levels at recurrence. The CEA staining status of metastatic tissue was positive in 7 patients (15.2\%) and negative in 9 patients (19.6\%). Thirty patients had positive serum CEA levels at recurrence. The CEA staining status of metastatic tissue was positive in 26 patients (56.5\%) and negative in 4 patients $(8.7 \%)$. Positive staining for CEA in metastatic tissue was significantly related to the serum CEA level at recurrence $(\mathrm{p}=0.0046)$. Even when the cutoff value was set at $10 \mathrm{ng} / \mathrm{ml}$, patients with positive staining for CEA in metastatic tissue included a significantly higher proportion of patients with positive serum CEA levels at the time of recurrence $(\mathrm{p}=0.0026)$ (table 5).

The survival rates after recurrence in the 33 patients with positive staining for CEA in metastatic tissue were $84.8 \%$ at 1 year, $57.6 \%$ at 3 years, and $38.5 \%$ at 5 years, respectively. In the 16 patients with negative staining for CEA in metastatic tissue, the survival rates at 1 year, 3 years, and 5 years were 100,54.6, and 67.7\%, respectively. Patients with positive staining for CEA had significantly lower survival rates, with a hazard ratio of 3.59 (95\% confidence interval, 1.39-12.23, $\mathrm{p}=0.0116$ ).

\section{Discussion}

CEA has been widely used as a tumor marker of colorectal cancer. Subsequent studies reported that CEA also resides in normal colorectal mucosa and that the
Table 3. CEA staining status of primary tumor and metastatic tissue

\begin{tabular}{llll}
\hline & \multicolumn{2}{l}{ CEA staining status } & $\mathrm{p}$ \\
\cline { 2 - 3 } & negative & positive & \\
\hline Primary tumor & $22(47.8)$ & $24(52.2)$ & 0.085 \\
Metastatic tissue & $13(28.3)$ & $33(71.7)$ & \\
\hline
\end{tabular}

Values are expressed as $\mathrm{n}(\%)$.

CEA content is markedly higher in tissue extracts of colorectal cancer than in tissue extracts of normal colorectal mucosa $[21,22]$.

CEA has been reported to participate in intercellular adhesion, protection against anoikis (apoptosis associated with cell detachment from the extracellular matrix), and increased metastatic potential [23]. Studies in experimental animals have shown that colorectal cancer cells that produce high amounts of CEA have high metastatic potential [24].

Previous studies examining the relations of the histologic type of cancer to the amount of CEA in, and CEA staining status of, cancer tissue have reported that welldifferentiated adenocarcinoma has the highest CEA content as well as strong staining intensity, while poorly differentiated adenocarcinoma has the lowest CEA content with weak staining intensity $[22,25,26]$. As for the localization of CEA in cancer tissue, immunohistochemical studies have shown that CEA is mainly localized at the apical surface of cancer glands in well-differentiated adenocarcinoma and at the entire surface of cancer cells and the intracytoplasm in moderately differentiated adenocarcinoma [27].

Several studies reported no correlation between the grade of CEA expression in cancer tissue and the serum 
Table 4. Relation between serum CEA levels at initial surgery and the CEA staining status of the primary tumor tissue

\begin{tabular}{|c|c|c|c|c|c|c|}
\hline \multirow{2}{*}{$\begin{array}{l}\text { CEA staining } \\
\text { status }\end{array}$} & \multicolumn{2}{|c|}{ Serum CEA level } & \multirow[t]{2}{*}{$\mathrm{p}$} & \multicolumn{2}{|c|}{ Serum CEA level } & \multirow[t]{2}{*}{$\mathrm{p}$} \\
\hline & $<5 \mathrm{ng} / \mathrm{ml}$ & $\geq 5 \mathrm{ng} / \mathrm{ml}$ & & $<10 \mathrm{ng} / \mathrm{ml}$ & $\geq 10 \mathrm{ng} / \mathrm{ml}$ & \\
\hline Positive & $9(19.6)$ & $15(32.5)$ & 1.000 & $12(26.1)$ & $12(26.1)$ & 0.072 \\
\hline Negative & $9(19.6)$ & $13(28.3)$ & & $17(37.0)$ & $5(10.8)$ & \\
\hline
\end{tabular}

Values are expressed as $\mathrm{n}(\%)$.

Table 5. Relation between serum CEA levels at recurrence and the CEA staining status of metastatic tissue

\begin{tabular}{|c|c|c|c|c|c|c|}
\hline \multirow{2}{*}{$\begin{array}{l}\text { CEA staining } \\
\text { status }\end{array}$} & \multicolumn{2}{|c|}{ Serum CEA level } & \multirow[t]{2}{*}{$\mathrm{p}$} & \multicolumn{2}{|c|}{ Serum CEA level } & \multirow[t]{2}{*}{$\mathrm{p}$} \\
\hline & $<5 \mathrm{ng} / \mathrm{ml}$ & $\geq 5 \mathrm{ng} / \mathrm{ml}$ & & $<10 \mathrm{ng} / \mathrm{ml}$ & $\geq 10 \mathrm{ng} / \mathrm{ml}$ & \\
\hline Positive & $7(15.2)$ & $26(56.5)$ & 0.0046 & $14(30.4)$ & $19(41.3)$ & 0.0026 \\
\hline Negative & $9(19.6)$ & $4(8.7)$ & & $12(26.1)$ & $1(2.2)$ & \\
\hline
\end{tabular}

Values are expressed as $\mathrm{n}(\%)$.

CEA level $[17,19,20]$. However, another study reported that the grade of CEA expression in cancer tissue is related to the serum CEA level [16]. Such inconsistent results may be attributed to methodological differences in the evaluation of the CEA expression grade in tissue. We based our study on the hypothesis that the lack of a strong correlation between CEA levels in cancer tissue and serum CEA levels is attributed to the fact that CEA localization and levels in cancer cells and the potential to release CEA into the blood are independent determinants of serum CEA levels.

Hamada et al. [27] reported that CEA localized to the basolateral membrane or stromal tissue leads to higher serum CEA levels than CEA localized to the luminal surface. This finding suggested that CEA flowing from interstitial tissue into blood vessels more strongly contributes to increased serum CEA levels than CEA flowing into the ductal lumen does. Patients with colon cancer who have lymphatic and vascular invasion in primary tumor tissue have been reported to have high serum CEA levels $[6,28]$. However, we found no such association in our studies (data not shown). Khoo et al. [17] reported that the CEA content of colon cancer tissue is higher in metastatic tissue than in primary tumor tissue. In our study, the rate of positive staining for CEA was slightly but not significantly higher in metastatic tissue.
Patients with positive staining for CEA in metastatic tissue had significantly a shorter survival than those with negative staining for CEA in metastatic tissue. Overexpression of CEA has been reported to inhibit the cytotoxic activity of natural killer cells and lymphocytes [29] and decrease tumor immune system activity, thereby providing a poorer outcome in patients with positive staining for CEA than those with negative staining for CEA.

Distant metastases of colon cancer to organs such as the liver and the lung are generally attributed to hematogenous metastasis [30], whereas metastatic recurrence after surgery is considered to result from the progression of micrometastasis already present at the time of initial diagnosis [31]. Available evidence suggests that the release of CEA from cancer tissue into the blood might be greater for metastatic tissue than primary tumor tissue and that the production level of CEA by cancer cells might be intimately related to the serum CEA level.

\section{Conclusions}

The immunohistochemical staining status of CEA in metastatic tissue is intimately related to the serum CEA level in patients with colon cancer. The serum CEA level 
is strongly suggested to be influenced by the ability of cancer tissue to release CEA into the blood, likely to be associated with the surrounding tissue environment, as well as by the CEA production capacity of cancer cells.

\section{Disclosure Statement}

The authors have no potential conflicts of interest to disclose.

\section{References}

1 Gold P, Freedman SO: Specific carcinoembryonic antigens of the human digestive system. J Exp Med 1965;122:467-481.

2 Ahnen DJ, Nakane PK, Brown WR: Ultrastructural localization of carcinoembryonic antigen in normal intestine and colon cancer: abnormal distribution of CEA on the surfaces of colon cancer cells. Cancer 1982;49:20772090.

-3 Dhar P, Moore T, Zamcheck N, Kupchik HZ: Carcinoembryonic antigen (CEA) in colonic cancer. Use in preoperative and postoperative diagnosis and prognosis. JAMA 1972;221:3135.

4 Livingstone AS, Hampson LG, Shuster J, Gold P, Hinchey EJ: Carcinoembryonic antigen in the diagnosis and management of colorectal carcinoma. Current status. Arch Surg 1974 109:259-264.

5 Mach JP, Jaeger P, Bertholet MM, Ruegsegger $\mathrm{CH}$, Loosli RM, Pettavel J: Detection of recurrence of large-bowel carcinoma by radioimmunoassay of circulating carcinoembryonic antigen (C.E.A.). Lancet 1974;2:535-540.

6 Zamcheck N, Doos WG, Prudente R, Lurie BB, Gottlieb LS: Prognostic factors in colon carcinoma: correlation of serum carcinoembryonic antigen level and tumor histopathology. Hum Pathol 1975;6:31-45.

7 Hirai H: A collaborative clinical study of carcinoembryonic antigen in Japan. Cancer Res 1977;37:2267-2274.

8 Midiri G, Amanti C, Consorti F, Benedetti M, Del Buono S, Di Tondo U, Castagna G, Peronace L, Di Paola M: Usefulness of preoperative CEA levels in the assessment of colorectal cancer patient stage. J Surg Oncol 1983;22: 257-260.

-9 Bruinvels DJ, Stiggelbout AM, Kievit J, van Houwelingen HC, Habbema JD, van de Velde CJ: Follow-up of patients with colorectal cancer. A meta-analysis. Ann Surg 1994;219:174182.

10 Locker GY, Hamilton S, Harris J, Jessup JM, Kemeny N, Macdonald JS, Somerfield MR, Hayes DF, Bast RC Jr: ASCO 2006 update of recommendations for the use of tumor markers in gastrointestinal cancer. J Clin Oncol 2006;24:5313-5327.

11 Labianca R, Nordlinger B, Beretta GD, Brouquet A, Cervantes A: Primary colon cancer: ESMO Clinical Practice Guidelines for diagnosis, adjuvant treatment and follow-up. Ann Oncol 2010;21(suppl 5):v70-v77.
12 Meyerhardt JA, Mangu PB, Flynn PJ, Korde L, Loprinzi CL, Minsky BD, Petrelli NJ, Ryan K, Schrag DH, Wong SL, Benson AB 3rd: Follow-up care, surveillance protocol, and secondary prevention measures for survivors of colorectal cancer: American Society of Clinical Oncology clinical practice guideline endorsement. J Clin Oncol 2013;31:4465-4470.

13 Labianca R, Nordlinger B, Beretta GD, Mosconi S, Mandala M, Cervantes A, Arnold D: Early colon cancer: ESMO Clinical Practice Guidelines for diagnosis, treatment and follow-up. Ann Oncol 2013;24(Suppl 6):vi64vi72.

14 Holyoke ED, Chu TM, Murphy GP: CEA as a monitor of gastrointestinal malignancy. Cancer 1975;35:830-836.

15 Mach JP, Vienny H, Jaeger P, Haldemann B, Egely R, Pettavel J: Long-term follow-up of colorectal carcinoma patients by repeated CEA radioimmunoassay. Cancer 1978;42: 1439-1447.

16 Park JW, Chang HJ, Kim BC, Yeo HY, Kim DY: Clinical validity of tissue carcinoembryonic antigen expression as ancillary to serum carcinoembryonic antigen concentration in patients curatively resected for colorectal cancer. Colorectal Dis 2013;15:e503-e511.

17 Khoo SK, Warner NL, Lie JT, Mackay IR: Carcinoembryonic antigenic activity of tissue extracts: a quantitative study of malignant and benign neoplasms, cirrhotic liver, normal adult and fetal organs. Int J Cancer 1973;11: 681-687.

18 Cosimelli M, De Peppo F, Castelli M, Giannarelli D, Schinaia G, Castaldo P, Buttini GL, Sciarretta F, Bigotti G, Di Filippo F, et al: Multivariate analysis of a tissue CEA, TPA, and CA 19.9 quantitative study in colorectal cancer patients. A preliminary finding. Dis Colon Rectum 1989;32:389-397.

19 Nakagoe T, Sawai T, Ayabe H, Nakazaki T, Ishikaw H, Hatano K, Kajiwara K, Miyashita K, Matsuo T, Nogawa T, Arisawa K: Prognostic value of carcinoembryonic antigen (CEA) in tumor tissue of patients with colorectal cancer. Anticancer Res 2001;21:3031-3036.

20 Nazato DM, Matos LL, Waisberg DR, Souza JR, Martins LC, Waisberg J: Prognostic value of carcinoembryonic antigen distribution in tumor tissue of colorectal carcinoma. Arq Gastroenterol 2009;46:26-31.
21 Boucher D, Cournoyer D, Stanners CP, Fuks A: Studies on the control of gene expression of the carcinoembryonic antigen family in human tissue. Cancer Res 1989;49:847-852.

22 Bhatnagar J, Tewari HB, Bhatnagar M, Austin GE: Comparison of carcinoembryonic antigen in tissue and serum with grade and stage of colon cancer. Anticancer Res 1999;19: 2181-2187.

23 Thomas P, Forse RA, Bajenova O: Carcinoembryonic antigen (CEA) and its receptor hnRNP M are mediators of metastasis and the inflammatory response in the liver. Clin Exp Metastasis 2011;28:923-932.

24 Wagner HE, Toth CA, Steele GD Jr, Thomas P: Metastatic potential of human colon cancer cell lines: relationship to cellular differentiation and carcinoembryonic antigen production. Clin Exp Metastasis 1992;10:25-31.

25 Martin F, Martin MS: Radioimmunoassay of carcinoembryonic antigen in extracts of human colon and stomach. Int J Cancer 1972;9: 641-647.

26 Guadagni F, Roselli M, Cosimelli M, Spila A, Cavaliere F, Arcuri R, D’Alessandro R, Fracasso PL, Casale V, Vecchione A, Casciani CU, Greiner JW, Schlom J: Quantitative analysis of CEA expression in colorectal adenocarcinoma and serum: lack of correlation. Int J Cancer 1997;72:949-954.

27 Hamada Y, Yamamura M, Hioki K, Yamamoto M, Nagura H, Watanabe K: Immunohistochemical study of carcinoembryonic antigen in patients with colorectal cancer. Correlation with plasma carcinoembryonic antigen levels. Cancer 1985;55:136-141.

28 Bivins BA, Meeker WR Jr., Griffen WO Jr, Pellegrini J, Parker JC Jr: Carcinoembryonic antigen (CEA) levels and tumor histology in colon cancer. J Surg Res 1975;18:257-261.

29 Gray-Owen SD, Blumberg RS: CEACAM1: contact-dependent control of immunity. Nat Rev Immunol 2006;6:433-446.

-30 Weiss L, Grundmann E, Torhorst J, Hartveit F, Moberg I, Eder M, Fenoglio-Preiser CM, Napier J, Horne CH, Lopez MJ, et al: Haematogenous metastatic patterns in colonic carcinoma: an analysis of 1541 necropsies. J Pathol 1986;150:195-203.

- 31 Sadahiro S, Suzuki T, Ishikawa K, Nakamura $\mathrm{T}$, Tanaka Y, Ishizu K, Yasuda S, Makuuchi H, Murayama C: Estimation of the time of pulmonary metastasis in colorectal cancer patients with isolated synchronous liver metastasis. Jpn J Clin Oncol 2005;35:18-22.
CEA Levels in Colon Cancer Tissue and in Serum at Initial Surgery 